\section{Mathematical Problem-Solving Processes of Students with Special Needs: A Cognitive Strategy Instruction Model 'Solve It!'}

\author{
Ufuk Özkubatta, ${ }^{\mathrm{k}}$, Alpaslan Karabulut ${ }^{\mathrm{b}}$, Emine Rüya Özmen $^{\mathrm{c}}$
}

\begin{tabular}{ll}
\hline Received: & 22 January 2020 \\
Revised: & 12 May 2020 \\
Accepted: $\quad$ & 13 June 2020 \\
ISSN: $1307-9298$ \\
Copyright @ IEJEE \\
www.iejee.com
\end{tabular}

DOI: $10.26822 /$ iejee.2020562131

\begin{abstract}
Being a cognitive strategy instruction model called 'Solve It!' involves cognitive and metacognitive elements. The model was developed by Montague (1992) as one of the process-based teaching strategies. The purpose of 'Solve It!' strategy is to teach the following seven cognitive strategy steps: read, paraphrase, visualize, hypothesize, predict, calculate, and check. Each cognitive strategy step has the following three metacognitive steps: ask, say, and check. 'Solve It!' strategy has been used to teach students with special needs on how to solve word problems. This study aimed to evaluate the studies using 'Solve It!' strategies. Therefore, this study reviewed studies by examining electronic databases, journal indexes, and references part of relevant studies. A total of 48 studies were found. These studies were reviewed in terms of inclusion and exclusion criteria, and 12 of them were used for descriptive analysis. The findings of the study revealed that 'Solve It!' was effective in teaching mathematical problem-solving skills for students with special needs. The findings were discussed in line with relevant literature, and some suggestions for future research, and practitioners were presented at the end of the paper.
\end{abstract}

Keywords: Cognitive Strategy Instruction, Mathematical Problem Solving, Solve It!, Students with Disabilities

\section{Introduction}

Mathematics is defined as a symbolic language in which people can share their thoughts about the amount of something with each other (Miller, Butler, \& Lee, 1998; Rivera, 1997). It is also considered a universal language throughout the world. Mathematics includes counting, measurement, arithmetic, computation, geometry, and algebra with the ability to think about situations related to a given quantity (Cawley, Parmar, Yan, \& Miller, 1998). The following four fields were identified by National Council of Teachers of Mathematics (2000) as the basic mathematics fields: problem solving, reasoning, communication, and interaction with the real world. By defining basic mathematics components, the association considers problem solving as an important component of mathematics (Parmar \& Cawley, 1997; Rivera, 1997). Although there are many definitions on the concept of problem solving, it is generally defined as a process that usually includes problem solving, combining, and analyzing skills (Cawley \& Miller, 1986). Additionally, problem solving includes one and/ or more than one step (Fuchs et al., 2004), and requires the differentiation of the calculations to be used in the solution process (Carpenter et al., 1993). The concept of problem solving may also contain information that is rarely unrelated or distracting (Passolunghi, Marzocchi, \& Fiorillo, 2005).

Many models on the problem-solving process have been developed since 1945 (Krawec, 2010). Among them, Polya (1957), Mayer (1985), and Montague (1992) have been cited by several studies in the relevant literature using mathematical problem-solving models (Karabulut \& Özkubat, 2019). The first mathematical problem-solving model was defined by George Polya in 1945. Polya's (1957) four basic steps proposed to solve mathematics problems are as follows: understanding the problem, planning, applying the plan, and controlling (backview). Another mathematical problem-solving model was developed by Mayer (1985). His model consists of two basic stages as follows: describing and solving the problem. Each step consists of four steps and two sub-steps (Krawec, 2010). These sub-steps are converting, merging, planning, and executing. The two problem-solving models have been considered important but are not described as 'innovative' in today's world (Sweeney, 2010). It is stated that in effective problem solving, the underlying power is metacognition defined as successfully completing a task and keeping track of him-/herself by being aware of his/her own thought processes with the control of his/her own performance (DeCorte, Greer, \& Verschaffel, 1996). The problem solvers using metacognition strategies can plan effectively and monitor their own performance in the solution process (Montague \& Applagate, 1993). In the context of this study, with the addition of metacognition strategies in the problem-solving process, problem solving was observed as a skill that includes not only cognitive processes but also the metacognitive processes. In this respect, Montague's problem-solving model provides a combination of cognitive and metacognitive strategies.

Montague (1991) stated that the model of effective problem solving in mathematics emerged as a result of her research on which the relevant effective variables in problem solving were examined. Those variables can be listed as follows: the usual problem solving, a solution of a mathematical problem, self-regulation, and successful problem solving (Montague, 1991). In this context, Montague (1991) examined the cognitive and metacognitive knowledge of problem solving, and the problem-solving processes of twice exceptional students, who have the combination of being gifted with superior ability and learning difficulties. In light of the study findings, cognitive and metacognitive strategies, and operations used by students who are proficient in problem solving were included in Montague's problem-solving model (Montague, Applegate, \& Marquard, 1993). Montague problem-solving skills require the use of cognitive and metacognitive strategies and procedures (Montague, 1992). Montague (1992) defined the seven cognitive strategies and calculations to solve a prob-

a, ${ }^{\star}$ Corresponding Author: Ufuk Özkubat. Gazi University, Gazi Faculty of Education, Department of Special Education, Ankara, Turkey. ORCID: http://orcid.org/0000-00029626-5112, E-mail: ufukozkubat@gazi.edu.tr

bAlpaslan Karabulut, Abant Izzet Baysal University, Faculty of Education, Department of Special Education, Bolu, Turkey. ORCID: http://orcid.org/0000-0002-7355-5109, E- mail: alpaslankarabulut@hotmail.com

EEmine Rüya Özmen, Gazi University, Gazi Faculty of Education, Department of Special Education, Ankara, Turkey. ORCID: http://orcid.org/0000-0002-0226-1672 E-mail: eruya@gazi.edu.tr 
lem successfully and developed metacognitive strategies and calculations that enable the use of those cognitive calculations (Montague, Warger, \& Morgan, 2000).

In this context, the 'Solve It! strategy developed by Montague is designed to improve the mathematical problem-solving performance of students with and without special needs (Montague, 1997). 'Solve It!' contains the elements of cognitive and metacognitive strategy teaching in mathematical problem solving and is a process-based approach used for students with learning disabilities (Daniel, 2003; Krawec, Huang, Montague, Kressler, \& De Alba, 2013; Montague, 1984; Montague, 1992; Montague \& Bos, 1986; Montague, Enders, \& Dietz 2011; Montague, Krawec, Enders, \& Dietz, 2014), intellectual disabilities (Chung \& Tam, 2005; Karabulut, 2015; Karabulut \& Özmen, 2018), autism spectrum disorders (Whitby, 2012), and for spina bfida (Coughlin \& Montague, 2011).

Students learn seven cognitive strategies and processes to solve mathematical problems effectively with the help of the first letters of cognitive strategies through the strategy of 'Solve It!': /read, paraphrase, visualize, hypothesize, estimate, compute, and check (RPV-HECC). Accurate realization of these cognitive processes is made possible by using the correct cognitive strategies (Montague, 1992). In the process of problem solving, cognitive strategy should be used to enable the cognitive process called 'understanding' to read a problem. Whether a problem is correctly comprehended by the students or not can be realized using 'paraphrasing the problem' cognitive strategy, and the use of 'conversion' cognitive process. Similarly, the use of the cognitive strategy 'calculation' needs to be applied in the cognitive process called 'computing' for a problem. While the metacognitive strategies are listed as self-instruction, self-questioning, and self-monitoring; the metacognitive processes are defined as the knowledge of strategy, the use, and control of it. In the model, the metacognitive strategies are not memorized with the help of a reminder, but they are only used to monitor students' own problem-solving practices (Montague, 1992). The cognitive and metacognitive strategies and processes are illustrated in Figure 1.

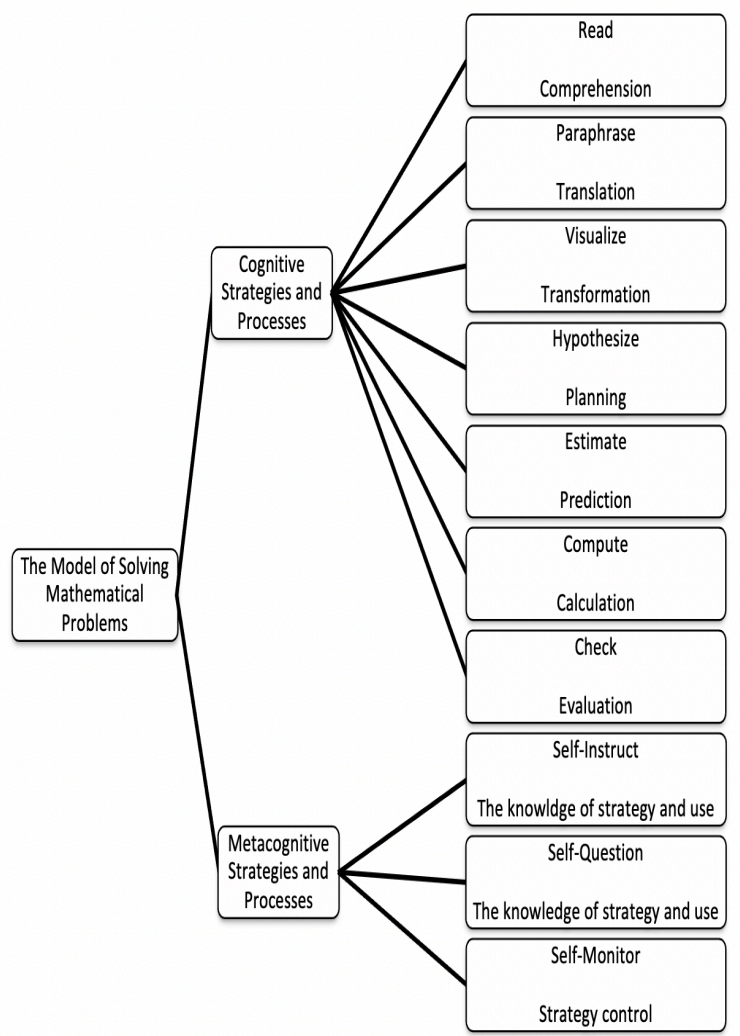

Figure 1. Montague Mathematical Problem-Solving Model
The 'Solve It!' strategy consists of a few steps and each step includes self-instruction, self-questioning, and self-monitoring strategies (e.g., say, ask, check). In other words, the 'Solve It!' strategy is a strategy that aims to teach the seven cognitive strategy steps, and three metacognitive strategy steps within each cognitive strategy steps. In this strategy, students are taught to read the problem carefully, express the problem with their own words, analyze the information, develop a plan, solve the problem, and control the solution (Reid \& Lienemann, 2006). In this context, the strategy of 'say, ask, check' that involves the cognitive and metacognitive processes and strategies to solve a problem is presented in Table 1.

The 'Solve It!' strategy was first published as a book to support the curriculum of mathematics in 2003 (Montague et al., 2014). However, related studies were conducted long before 2003 (Montague, 1984; Montague, 1992; Montague \& Bos, 1986). These studies claimed that 'Solve It!' strategy improved students' problem-solving performance by using different research designs such as experimental designs, single subject experimental designs, semi-experimental designs, and random clustering designs. The first study to test the effectiveness of the 'Solve It!' strategy was conducted by Montague and Bos (1986). The 'Solve It!' strategy was applied to six fourthgrade high school students with limited mathematical skills. The findings of the study using a multiple baseline design across individuals from single-subject experimental designs revealed that all participants' problem-solving performance were developed and that they were able to generalize their strategies to different and more difficult problems. Besides being the first study, the study was also important because it specified the cognitive strategy steps in the 'Solve It!' strategy. As a matter of fact, Montague (1984) mentioned eight cognitive strategy steps in the problem-solving process in her thesis. This strategy step is the 'state the problem' step that this study does not have in the current model. Following this research, the cognitive strategy steps remained valid, and the number of cognitive strategy steps taken in the 'Solve It!' strategy has been determined as seven. In the second study, Montague (1992) examined the effectiveness of the following two components: teaching cognitive and metacognitive strategies in the problem-solving process. Six middle school students with learning disabilities participated in the research. The intervention was completed in two phases. In the first stage, half of the participants participated in cognitive strategy teaching, while the other half participated in metacognitive strategy teaching. In the second stage, the participants participated in both practices. The research findings revealed that students who were taught cognitive strategies quickly went to the stage of mastery. In addition, problem-solving performance of all students involved in the study was developed in one-, two-, and three-step mathematic problems.

The 'Solve It!' strategy was used in the research conducted in the 2000s (Daniel, 2003), and it has gained momentum since 2010 (Krawec et al., 2013; Montague et al., 2014; Montague et al., 2011). Daniel (2003) examined the impact of 'Solve It!' strategy teaching on problem-solving performance of secondary school students with learning difficulties. Research findings showed that 'Solve It' strategy improved the problem-solving performance of students with learning disabilities and students' implementation levels of the strategies have increased. Krawec et al. (2013) examined the impact of the 'Solve It!' and the strategy knowledge of the students. In the study conducted on the 7th and 8th graders, the participant groups consisted of 77 students with learning disabilities and 83 students with average achieving students. Students with learning disabilities and average achieving students were divided into two groups: an individual intervention and comparison groups. The intervention process was conducted three days a week, and 30-minutes of problem-solving sessions were organized each week. The total implementation continued for six months. The research findings revealed that according to the Math Problem Solving Assessment-Short Form (MPSA-SF) pre- 
Table 1. The Strategy of 'Say, Ask, Check'

\begin{tabular}{|c|c|c|}
\hline $\begin{array}{l}\text { Cognitive strategy and } \\
\text { the steps of the operation }\end{array}$ & The metacognitive strategy 'say, ask, check' & Examples \\
\hline \multirow{3}{*}{$\begin{array}{l}\text { Read } \\
\text { (for understanding) }\end{array}$} & $\begin{array}{l}\text { The aim of say (self-instruction): The student reads the question } \\
\text { carefully before implementing an operation. }\end{array}$ & $\begin{array}{l}\text { Say: I will read the question, and if do not under- } \\
\text { stand it, I will read it till I do. }\end{array}$ \\
\hline & $\begin{array}{l}\text { The aim of ask (self-questioning): Has the student fully understood } \\
\text { the question which has been directed to him/her? }\end{array}$ & $\begin{array}{l}\text { Ask: Now that I have read the question, have I fully } \\
\text { understood it? }\end{array}$ \\
\hline & $\begin{array}{l}\text { The aim of check (self-monitoring): If the student has understood the } \\
\text { question, he/she can start solving it. }\end{array}$ & $\begin{array}{l}\text { Check: I have understood the problem. Now I can } \\
\text { proceed. }\end{array}$ \\
\hline \multirow{3}{*}{$\begin{array}{l}\text { Paraphrase } \\
\text { (your own words) }\end{array}$} & $\begin{array}{l}\text { The aim of say (self-instruction): To state that he/she has understood, } \\
\text { the student paraphrases. }\end{array}$ & $\begin{array}{l}\text { Say: I will underline the words that are related to } \\
\text { the problem. I will paraphrase the question. }\end{array}$ \\
\hline & $\begin{array}{l}\text { The aim of ask (self-questioning): Does the student have the ability } \\
\text { to the question being asked to him/her? }\end{array}$ & $\begin{array}{l}\text { Ask: Have I underlined the most important fea- } \\
\text { tures or words in the problem? }\end{array}$ \\
\hline & $\begin{array}{l}\text { The aim of check (self-monitoring): Make sure that highlighted key- } \\
\text { words are relevant. }\end{array}$ & $\begin{array}{l}\text { Check: I have found the necessary words and fea- } \\
\text { tures they will help me solve the problem. }\end{array}$ \\
\hline \multirow{3}{*}{$\begin{array}{l}\text { Visualize } \\
\text { (a picture of a diagram) }\end{array}$} & $\begin{array}{l}\text { The aim of say (self-instruction): Students draw to reinforce their } \\
\text { understanding of the problem. }\end{array}$ & Say: I will draw a diagram of the problem. \\
\hline & $\begin{array}{l}\text { The aim of ask (self-questioning): Is there any compatibility between } \\
\text { the problem and drawing? }\end{array}$ & Ask: Do my drawings represent the problem? \\
\hline & $\begin{array}{l}\text { The aim of check (self-monitoring): The drawing includes visual key } \\
\text { concepts related to the mathematics problem. }\end{array}$ & $\begin{array}{l}\text { Check: The drawing contains the basic parts of the } \\
\text { problem. }\end{array}$ \\
\hline \multirow{3}{*}{$\begin{array}{l}\text { Hypothesize } \\
\text { (a plan to solve the } \\
\text { problem) }\end{array}$} & $\begin{array}{l}\text { The aim of say (self-instruction): Student creates a plan for solving } \\
\text { the problem. }\end{array}$ & $\begin{array}{l}\text { Say: I am going to make a plan to solve the prob- } \\
\text { lem. }\end{array}$ \\
\hline & $\begin{array}{l}\text { The aim of ask (self-questioning): Which plan helps a student solve } \\
\text { the problem? }\end{array}$ & $\begin{array}{l}\text { Ask: What about the first step in this plan? What } \\
\text { about the next step in the plan? }\end{array}$ \\
\hline & $\begin{array}{l}\text { The aim of check (self-monitoring): The plan is suitable for solving } \\
\text { this problem. }\end{array}$ & $\begin{array}{l}\text { Check: My plan has the necessary steps to solve } \\
\text { this problem. }\end{array}$ \\
\hline \multirow{3}{*}{$\begin{array}{l}\text { Estimate } \\
\text { (predict the answer) }\end{array}$} & $\begin{array}{l}\text { The aim of say (self-instruction): Student evaluates value for estimat- } \\
\text { ing the answer or uses other strategies. }\end{array}$ & $\begin{array}{l}\text { Say: I will guess what the correct answer of the } \\
\text { problem is. }\end{array}$ \\
\hline & $\begin{array}{l}\text { The aim of ask (self-questioning): Which prediction strategy does } \\
\text { the student use to predict the answer? }\end{array}$ & $\begin{array}{l}\text { Ask: In my estimation, which numbers can be used } \\
\text { to solve the problem? }\end{array}$ \\
\hline & $\begin{array}{l}\text { The aim of check (self-monitoring): All of the important problem } \\
\text { information was used to estimate the correct answer. }\end{array}$ & $\begin{array}{l}\text { Check: I have not missed any important informa- } \\
\text { tion in my estimation. }\end{array}$ \\
\hline \multirow{3}{*}{$\begin{array}{c}\text { Compute } \\
\text { (do the arithmetic) }\end{array}$} & $\begin{array}{l}\text { The aim of say (self-instruction): Student will be able to follow the } \\
\text { plan to calculate the solution of the problem. }\end{array}$ & Say: Do the operations in the right order. \\
\hline & $\begin{array}{l}\text { The aim of ask (self-questioning): Is the answer consistent with the } \\
\text { prediction made? }\end{array}$ & $\begin{array}{l}\text { Ask: How many steps are needed? Are the opera- } \\
\text { tions in the right order? }\end{array}$ \\
\hline & $\begin{array}{l}\text { The aim of check (self-monitoring): The steps in the plan were fol- } \\
\text { lowed and completed in the correct order. }\end{array}$ & $\begin{array}{l}\text { Check: I have done all the work in the correct or- } \\
\text { der to solve the problem. }\end{array}$ \\
\hline \multirow{3}{*}{$\begin{array}{l}\text { Check } \\
\text { (make sure everything is } \\
\text { correct) }\end{array}$} & $\begin{array}{l}\text { The aim of say (self-instruction): Student reviews the calculation } \\
\text { steps to verify the answer. }\end{array}$ & Say: I will review the steps of the calculation. \\
\hline & $\begin{array}{l}\text { The aim of ask (self-questioning): Did the student check all the steps } \\
\text { to solve the problem and were all the calculations correct? }\end{array}$ & $\begin{array}{l}\text { Ask: Have I reviewed every step in my answer and } \\
\text { checked my work? }\end{array}$ \\
\hline & $\begin{array}{l}\text { The aim of check (self-monitoring): The problem solution seems to } \\
\text { be done correctly. }\end{array}$ & $\begin{array}{l}\text { Check: I have done all the steps in the correct or- } \\
\text { der to solve the problem. If I have not done, I will } \\
\text { check the previous steps, I will ask for help when } \\
\text { I need to. }\end{array}$ \\
\hline
\end{tabular}

test and post-test results, the intervention group students started to use more strategies than the comparison group students. The average achieving group students compared to those with learning disabilities were reported to use different and more strategies in the problem-solving process. After the implementation, all students in the intervention group showed significant improvement compared to their peers in the comparison group.

Another study of Montague et al. (2011) examined the effect of the problem-solving intervention of 8th students with learning difficulties in problem solving. Forty schools were classified in the study according to their average mathematical performance and socioeconomic status. The group of participants consisted of 779 low and average achieving students, 78 of whom were with learning disabilities. Within the scope of the research, the students in the intervention group attended the training program on intervention three days a week and held weekly problem-solving sessions. The findings revealed that the mathematical performance of low and average level students with learning difficulties in the intervention program increased more than those of their peers in the comparison group. Moreover, Montague et al. (2014) examined the effect of 'Solve It!' interventions on the problem-solving performance of 7 th grade students. The students who participated in the study were divided into the following three groups: low level, average level, and students with learning difficulties. They were examined in intervention and comparison groups according to their average mathematical performance and socioeconomic status. The group of participants consisted of 86 students with learning difficulties and 973 students with low and average achieving. Students who were in the intervention group participated in the following teaching stages: activating the pre-knowledge 
for the implementation of the strategies and procedures required for problem solving, discussing the strategy, explaining the strategy, and describing how these strategies will help the improvement of the problem-solving skills, using the strategy appropriately with examples, using self-regulation strategies independently to follow their performance up three times a week for eight months until the problem-solving process was completed. The findings showed that the performance of the students in the intervention group increased compared to the peers in the comparison group, and especially the low achieving students' performance differed significantly compared to the peers in the comparison group.

Research on students with learning disabilities also revealed that the 'Solve It!' strategy was used to improve students' problem-solving performance and it was found as an effective strategy (Daniel, 2003; Krawec et al., 2013; Montague, 1984; Montague, 1992; Montague et al., 2014; Montague \& Bos, 1986; Montague et al., 2011). Research showed that the 'Solve It!' strategy could be taught by clear expressions by following the generalization stages, being a model, voiced thinking, implementing guided and independent practices. It was also emphasized that cognitive and metacognitive strategies applied in problem-solving processes improve the mathematical skills of students with learning disabilities.

Studies have indicated that students develop problem-solving skills and generalize the learned strategy to other disciplines by systematically presenting and following the strategies of teaching steps (Smith \& Alley, 1981). Some studies showed that process-based teaching is not only effective in helping students with different types of problems (Bennet, 1982) but also effective in improving students' abilities to express problems and self-instruction to develop problem-solving skills (Case \& Harris, 1988). Based on these findings, it is safe to say that the 'Solve It!' strategy teaches students how to implement the problem-solving process and the strategies it includes because it is a process-based problem-solving strategy and designed to teach the metacognitive activities associated with each cognitive process (Montague et al., 2014). The results about the effectiveness of studies examining students with learning disabilities showed that the 'Solve It!' strategy should be implemented on the students with inabilities, such as autism spectrum disorder (Whitby, 2012), intellectual disabilities (Chung \& Tam, 2005; Karabulut, 2015; Karabulut \& Özmen, 2018), and spina bfida (Coughlin \& Montague, 2011) to enable them to improve their problem-solving performance. Stating that the number of students with autism spectrum disorders increased faster than all other disabled groups, Whitby (2012) maintained that there is a need for effective teaching strategies that can be applied to students with autism spectrum disorders and analyzed the effectiveness of the 'Solve It!' problem strategy in solving math problems.

Three middle school students with autism spectrum disorders were included in the study in which multiple baselines were used across participants design. As a result of the ' Solve It! strategy, the problem-solving performance of the three students examined by this study increased. In this respect, Whitby (2012) asserted that 'Solve It!' strategy was an effective intervention in the development of problem-solving processes for students with autism spectrum disorders. Additionally, Chung and Tam (2005) applied Montague's strategy (1992) by adapting the cognitive strategy teaching routines in their study with 30 students with mental disorders. In the study, the strategy teaching components developed by Montague (1992) (i.e., say, ask, and check) were adapted to the cognitive strategy teaching model (see Table 1). The students in the study were divided into three groups: traditional teaching, teaching via examples, and cognitive strategy teaching. It was revealed that the students in the cognitive teaching group made more progress than the students in other groups. Furthermore, Coughlin and Montague (2011) examined the effectiveness of the 'Solve It! strategy to improve the math problem-solving performance of three students with spina bfida. The study used multiple baselines across individuals and included two steps of intervention. One-step mathematical problems were used in the first stage, while two-step mathematical problems were used in the second stage. According to findings, it appears that problem-solving performance of all participants have developed. Recent studies of Karabulut (2015) and Karabulut and Özmen (2018) aimed to examine the effect of the 'Solve It!' strategy on the problem-solving performance of students with mild intellectual disabilities. It was observed that these students changed their use, and control of their problem-solving strategies and information qualitatively; in addition, they were able to generalize the strategies they used to solve different types of problems and maintain the generalizations.

Studies on students with spina bifida, autism spectrum disorders, and intellectual disabilities revealed that the 'Solve It!' strategy is an effective strategy on (Chung \& Tam, 2005; Coughlin \& Montague, 2011; Whitby, 2012). Poor organizational skills, such as planning, remembering previous knowledge, and self-control, which are associated with the autism spectrum disorder, affect their problem-solving performance (Happe, Booth, Charlton, \& Hughes, 2006). Similarly, students with intellectual disabilities are limited in solving problems by understanding and using mathematical concepts because of their inefficient strategy repertoires (Xin \& Jitendra, 1999). The low level of attention and inability to decide on the proper computing types of students with spina bfida have a negative effect on their performance in their problem-solving processes (Burmeister et al., 2005). In light of these findings, it would be safe to say that the 'Solve It!' strategy provides support to these students on how to interpret a math problem, how to analyze given information, how to develop a logical solution plan to solve a problem, and how to evaluate alternative solutions.

Only limited studies have examined the effects of intervention programs applied to support the problem-solving performance of students with special needs in Turkey (Baki, 2014; Karabulut, 2015; Karabulut \& Özmen, 2018; Karabulut, Yıkmış, Özak, \& Karabulut, 2015; Kot \& Yıkmış, 2018; Özsoy, 2005; Özsoy, 2017; Tuncer, 2009; Tufan \& Aykut, 2018). In addition, there are no studies on identifying problem-solving processes of students with special (Özkubat, 2019; Özkubat \& Özmen, 2018). The literature in Turkey on the 'Solve It!' strategy revealed that there are only two studies that aim to support the problem-solving performance of the students (Karabulut, 2015; Karabulut \& Özmen, 2018). Therefore, a realization phase was reached on the importance of examining the studies related to the use of 'Solve It!' strategy, which is a mathematical intervention for students with learning disabilities, autism spectrum disorder, mental and physical disabilities in the international literature. Hence, planning the study, developing appropriate intervention programs and using scientific evidence in Turkey will be possible. This teaching strategy is only applied to mentally disabled students in Turkey; however, it is believed that this research will guide the use of this strategy to cover other types of disabilities, such as learning difficulties and autism spectrum disorders. In addition, this study will shed light on future studies by bringing a different perspective to the studies aiming to conduct on the 'Solve It!' strategy. In this respect, this study aimed to examine the studies using the 'Solve It!' strategy in terms of a number of variables.

\section{Methodology}

This study covers the research articles and dissertations published in journals using the applications of problem-solving interventions using the cognitive strategy teaching model 'Solve It!' including cognitive and metacognitive elements. This part of the stud presented the necessary information about the criteria for inclusion of the articles and theses in this study, the literature review, coding of the articles and theses, descriptive analysis process, and the reliability of the coders. 


\section{Criteria for Inclusion}

For the inclusion and non-inclusion of the articles and theses in this study, The following basic selection criteria were determined: a) The research group should include students with special needs, b) the study should include the intervention of the 'Solve It!' problem-solving strategy as an independent variable and, c) the study should be published in a national or international peer-reviewed journal. Criteria for the inclusion of the theses are as follows: a) The participant group of the theses should consist of students with special needs, b) the theses should include the intervention of the 'Solve It!' problem-solving strategy as an independent variable and, c) the theses should be master's theses and/or doctorate dissertations. Studies that did not provide the findings of special needs students after the intervention strategies were not included in this study.

\section{Search Procedures}

First of all, EBSCOhost, Education Research Complete, Education Resources Information Center (ERIC), Web of Science, Psychological Abstracts Index (PsycINFO), ULAKBIM National Databases (UVT), ProQuest Dissertations \& Theses Global, Google, and Google Scholar search engines were used to determine the articles. The search was performed by entering keywords in specified search engines. The keywords were typed in Turkish and English. The following keywords were used: The 'Solve It!' math problem solving, math intervention, cognitive strategy instruction, math instruction, computation, and algebra, arithmetic. As a result of the scanning with the aforementioned keywords, 48 studies were obtained. Titles, summaries, and keywords of the studies were analyzed, and six chapters were obtained by eliminating book sections, reports. In addition to this step, the articles containing problem-solving interventions were included in the following key journals between 1990 and 2018: Exceptional Children, Learning Disabilities Quarterly, Journal of Learning Disabilities, Learning Disabilities Research \& Practice, Remedial \& Special Education, and Journal of Special Education.
Secondly, the keywords used in determining the articles and theses were searched using the ProQuest Digital Dissertations search engine in Turkish and English. As a result of the literature review, two more studies were included. Both studies were doctoral dissertations. In the third and final steps, the aforementioned keywords were searched through the Council of Higher Education's National Thesis Center website to identify the graduate theses examining the 'Solve It!' strategy in Turkey; thus, one more study was included. Theses with electronic access were obtained from the Internet, and those with no electronic access were acquired from the libraries of the universities. The data were collected, and search filters were applied according to the Prisma Flow Diagram represented in Figure 2.

\section{Article Coding and Reliability}

The selection of articles and theses was made by considering the basic selection criteria for inclusion of articles and theses. First, a form has been created by taking the basic selection criteria into consideration. The first author read and examined $70 \%$ of the articles and theses in detail, while the second author read and examined $30 \%$ of them. They were then recorded in the assigned form. The review process was conducted by the first and second authors. As a result of the review, a total of 12 papers (nine articles and three dissertations) published in seven different journals that fit the pre-decided criteria were reached. Articles and theses included in the scope of the study are shown in the references part with $\left(^{*}\right)$. The reliability among coders in the study was calculated using the following formula: "Consensus / [Consensus + disagreement] $\times 100$ " by comparing the $25 \%$ of the research results and data obtained by the first and second researchers.

\section{Descriptive Analysis Process}

The articles and theses were examined in accordance with the research review form developed by the researchers to evaluate the data at hand, a) the number of participants, b) class and age, c) gender, d) diagnosis of participants, e) target skill, f) research pattern, g) environment of the ap-

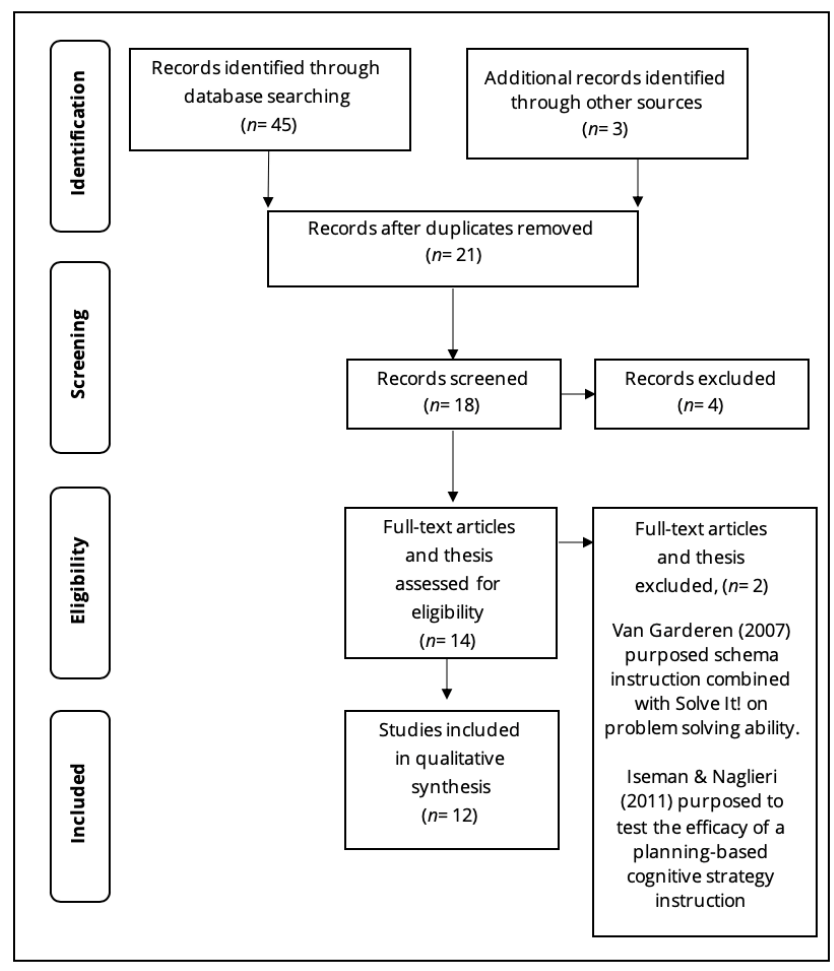

Figure 2. Flow Diagram (The PRISMA Statement) 
plication, h) generalization and monitoring, i) reliability, and j) findings. Table 2 depicts the information regarding the studies investigated in this research.

\section{Results}

The results of these studies were analyzed through descriptive analysis and reliability.

\section{Descriptive Analysis Findings}

\section{Participants}

The studies included in this paper were examined in terms of the following variables: a) the number of participants, b) class and age, c) gender, and d) diagnostic variables. Demographic information is presented in Table 2. There are 2078 participants in the included studies: $3 \%$ of the participants ( $n=$ $58)$ were in the $8-12$ age range, $0.4 \%(n=9)$ in the $12-14$ age range, $0.6 \%(n=12)$ in the $15-19$ age range, while the majority of the participants in the study did not specify their age levels $(n=1999,[96 \%])$. More than half of the participants were girls (1130, [54\%]) and $948(46 \%)$ of them were boys. As for the grade level variables, $97 \%$ of the participants $(n=2032)$ were at fifth-eighth graders (i.e., at middle school level), and that of $\% 1(n=16)$ was at $9-12$ graders. No information regarding participants' grade levels was included in $2 \%(n=30)$ of the studies. When the participants were examined by diagnosis, it is observed that the majority of the participants are students showing typical development $(n=1766,[85 \%])$. The other participants were students with learning disabilities $(n=269$, [13\%]), students with intellectual disabilities $(n=36,[1.6 \%])$, students with autism spectrum disorders $(n=3,[0.2 \%])$, and students with spina bfida ( $n=4,[0.2 \%]$ ).

Table 2. Demographic Information of the Participants

\begin{tabular}{cccc}
\hline Variables & & $f$ & $\%$ \\
\hline \multirow{4}{*}{ Age } & $8-12$ & 58 & 3 \\
\cline { 2 - 4 } & $12-14$ & 9 & 0.4 \\
\cline { 2 - 4 } & $15-19$ & 12 & 0.6 \\
\cline { 2 - 4 } Gender & Non-defined & 1999 & 96 \\
\cline { 2 - 4 } & Female & 1130 & 54 \\
\cline { 2 - 4 } Grade level & Male & 948 & 46 \\
\cline { 2 - 4 } & 5-8. Grade level & 2032 & 97 \\
\cline { 2 - 4 } & 9-12. Grade level & 16 & 1 \\
\cline { 2 - 4 } & Non-defined & 30 & 2 \\
\cline { 2 - 4 } Diagnosis & Learning disabilities & 269 & 13 \\
\cline { 2 - 4 } & Autism spectrum disorder & 3 & 0.2 \\
\cline { 2 - 4 } & Intellectual disabilities & 36 & 1.6 \\
\cline { 2 - 4 } & Spina bfida & 4 & 0.2 \\
\cline { 2 - 4 } & Typical development & 1766 & 85 \\
\hline & Total & 2078 & 100 \\
\hline
\end{tabular}

\section{Target Skills}

The effectiveness of the 'Solve It! strategy, one-step problems (easy problems that can be solved in only one step), two-step problems (medium-level problems that can be solved in two steps), three-step problems (difficult problems that can be solved in three steps) was investigated in this study.

\section{The Environments of Intervention}

As can be seen in Table 3, the intervention environment of the research, the environment was distributed evenly. It appears that $27 \%$ of the studies $(n=3)$ were applied in support rooms, $27 \%$ of them were administered in education classrooms, and
$27 \%$ of them were conducted in training support rooms initially and then in regular education classrooms. Besides, the intervention in two of the studies (19\%), was performed in an empty classroom in the school.

Research Designs

Single-subject experimental patterns $(n=7,[58 \%])$ and other experimental designs ( $n=5$, [42\%]) were used by the reviewed studies. As for the research findings in terms of single-subject experimental designs, it appears that multiple baseline designs were used in four studies (33\%) and multiple probe designs were used in three studies (25\%). As for other experimental designs, it appears that the cluster-randomized design was used in two studies (17\%), the pretest-posttest design was used in two studies (17\%), and the cross-subject design was used in one study (8\%).

Table 3. The Environments of the Intervention and Information about Designs Used

\begin{tabular}{lccc}
\hline Variables & Multiple baseline design & $f$ & $\%$ \\
\hline \multirow{2}{*}{$\begin{array}{c}\text { Single-subject } \\
\text { experimental } \\
\text { designs }\end{array}$} & Multiple probe design & 4 & 33 \\
\cline { 2 - 4 } & Total & 3 & 25 \\
\hline & Cluster randomized design & 2 & 17 \\
\cline { 2 - 4 } $\begin{array}{c}\text { Experimental } \\
\text { designs }\end{array}$ & Pretest-posttest design & 2 & 17 \\
\cline { 2 - 4 } & Cross subjects design & 1 & 8 \\
\cline { 2 - 4 } & Total & 5 & 42 \\
\cline { 2 - 4 } & Support room & 3 & 25 \\
\cline { 2 - 4 } & Support room/ Education classroom & 3 & 25 \\
\cline { 2 - 4 } & Empty classroom & 3 & 25 \\
\cline { 2 - 4 } Environments & Total & 12 \\
\cline { 2 - 4 } & Supsroom & 3 & 25 \\
\hline
\end{tabular}

\section{The Results of Effectiveness}

The examination of the visual graphics and written findings of 12 studies revealed that the 'Solve It!' strategy was effective in the acquisition of the targeted skills. The findings of the examination of the graphs of single-subject experimental designs in which the 'Solve It!' strategy was discussed showed that the curves at the starting level had an increase slope in the intervention phases. In other experimental designs, it was revealed that when the 'Solve It!' strategy was applied as a result of statistical operations, it had an effect on the acquisition of target behaviors.

\section{Reliability}

The inter-coder reliability among coders for the descriptive analysis process was $92 \%$ and ranged between $\% 90$ - $\% 96$.

\section{Discussion}

This research aimed to examine the studies using the 'Solve It!' strategy by different variables. The examination of the reviewed studies revealed the following three basic findings: First, it is effective to use the 'Solve It!' strategy for the problem-solving abilities of students with learning disabilities, autism spectrum disorders, spina bfida, and intellectual disabilities. Second, the strategy has the potential to lead to progress in the problem-solving abilities of students with and without disabilities. Finally, more studies should be conducted for the purpose of supporting the problem-solving skills of students with special needs.

The findings of the diagnostic variables, in line with the descriptive analysis findings, revealed that the majority of the participants with special needs were students with learning 
disabilities. The limitations of the students with learning disabilities in the field of mathematics skills are considered as one of the main problems in the literature (Miller \& Mercer, 1997; Montague, 1992). To solve the math problems, students need to read the problem, decide what to do, solve the problem, and check the logic of their answers (Montague, Warger, \& Morgan, 2000). Similarly, in the 'Solve It!' strategy, students are able to understand the mathematical problems, analyze the information given in the problem, develop logical plans to solve the problem, and evaluate their solutions (Montague, Warger, \& Morgan, 2000). Therefore, it would be safe to say that the 'Solve It!' strategy improves the students' problem-solving performance.

The processes are complex and sequential in problem-solving stages. In other words, the right solution requires the correct implementation of the previous step makes this process difficult for students with special needs (litendra et al., 2009). Likewise, in this research the 'Solve It!' strategy includes the following steps: how to solve the problem, how to interpret the problem with their own sentences, how to analyze the information, how to develop a plan, how to solve the problem, and how to check the solution (Montague et al., 2014; Montague et al., 2011; Krawec et al., 2013). These steps are sequential with each other (Reid \& Lienemann, 2006). In addition, the teaching of metacognitive strategies is associated with each cognitive process. Thus, students learn to manage the process by using these strategies.

Solving math problems is considered a difficult skill for many students because of the complexity of the problem-solving processes (Jonassen, 2003; Schurter, 2002). The examination of the problem-solving teaching practices revealed that the sequential steps that students have to take to solve the problem are used and these steps do not cover the whole problem-solving process all the time (Montague, 1992). Although the stages representing this process show the students the way to solve the problems, some steps are not taken in practice and the metacognitive strategies which are used to get self-monitoring and self-evaluation conducted during the problem-solving process are not discussed thoroughly. It is not enough to know these stages to be a good problem solver, especially for students with difficulties in learning and managing their own learning processes, and for those with limitations in their cognitive processes. So as to say, the 'Solve It!' strategy enables students to learn the problem-solving process through the steps involving the entire process and the strategies to be used in these steps. The purpose of the cognitive strategy teaching is to teach students to think and act like good problem solvers or strategic learners (Montague, 2008). The cognitive routines used in this teaching technique are conveyed to students through loud thinking models, enabling the students' strategy applications to be independent thanks to the appropriate support, and immediate feedback on student's performance provided through student and teacher interaction (Güzel-Özmen, 2008). Students with special needs feel the need to organize their own thinking processes (Krawec et al., 2013; Montague et al., 2011; Montague et al., 2014). In this context, one of the important components of the 'Solve It!' strategy is supporters that can be expressed as procedural facilitators (Chung \& Tam, 2005; Montague, 2008). The master problem solver's application of the strategy steps by thinking loudly serves as a bridge between the students' existing skills and knowledge and their intended target (Güzel-Özmen, 2006). The support provided at the beginning of the strategy education is gradually withdrawn, and finally, the student is able to implement the strategy independently (Chung \& Tam, 2005). Another important concept in the 'Solve It!' strategy is the visualization strategies. The visual strategies presented by students with special needs, by organizing and presenting problem-solving steps to provide information about the problem due to the difficulties in coordinating the working memory, are of great benefit in solving the problem (Geary, 2004; Hughes et al., 2003). Accordingly, visualization in the 'Solve It!' strategy increases the students' understanding of the problem by bringing various information together in the problem (Ives, 2007; Jitendra et al., 2009; Van Garderen, 2007). In addition to the fact that the visualization of the problems enables students to solve the problems (Ives, 2007; Van Gardener, 2007), it is also stated that this ensures that the information will be stored and thus accelerate the processing of information by supporting the working memory (Keeler \& Swanson, 2001). Short term memory problems of the students with special needs include the problem of bringing information back to their minds immediately after hearing or seeing information while the working memory problems arise from grouping information and cognitive processing faults, such as coding (Chung \& Tam, 2005; Swanson \& Jerman, 2006). In light of this information, it can be stated that students with learning disabilities can facilitate their math problem-solving processes by using the problem visualization strategy and supporting their memories. Many students with special needs face failure in the field of mathematics (Jonassen, 2003). Therefore, they can develop negative attitudes toward learning mathematics and use their existing potentials (Montague, 1997). The effect of perception, attitude, and motivation about learning mathematics cannot be disregarded because the student thinking that he/she cannot do this, simply does not try to achieve it (Karabulut \& Özmen, 2018). Accordingly, it also supports the students in developing positive perceptions about problem solving through their implementation of the strategies in the 'Solve It!' strategy. Indeed, studies using the 'Solve It!' strategy (Daniel, 2003; Montague, 1992; Whitby, 2009) revealed that there is a relationship between the increase in the number of problem solving and the increase in the performance of the applying the strategy, and the attitude. It has been found that different teaching strategies develop the attitude toward mathematics and mathematics problem-solving approaches positively. It was also stated that there is a relationship between problem-solving performance of students with learning disabilities, and the difficulty level of the problem (Bryant, Bryant, \& Hammill, 2000; Powell, 2011).

When faced with difficult problems, students with learning disabilities are not able to organize the information in their minds because they are limited in understanding the language used in the problem. Also, the multi-staged problems cause more confusion to these students in the problem-solving process (Powell et al., 2008). Research findings regarding target skills reveal that the problems used in related studies are the same problems included in the 'Solve It!' strategy. The problems used in the 'Solve It!' strategy range from easy to difficult (one, two, three-stepped) in terms of difficulties and the number of operations needed. In accordance with this information, students' problem-solving strategies can be developed by arranging the problems to be used in this intervention group of students with learning difficulties wisely (Hunt and Vasquez, 2014). In light of this information, it can be stated that the difficulties of the problems within the 'Solve It' strategy, and the number of transactions listed from easy to difficult (one, two, three steps) are an important variable for the effective implementation of this strategy (Karabulut \& Özmen, 2018).

The participating groups of the study included students with learning disabilities, intellectual disabilities, autism spectrum disorders, spina bfida, and typical developmental patterns. The effectiveness of 'Solve It!' strategy applied in these studies has been evaluated (Chung \& Tam, 2005; Coughlin \& Montague, 2011; Daniel, 2003; Karabulut, 2015; Karabulut \& Özmen, 2018; Krawec et al., 1984; Montague, 1992; Montague et al., 2011; Montague et al., 2013; Montague et al., 2014; Montague \& Bos, 1986; Whitby, 2012). It was found that students with and without special needs made improvement. The intervention group showed rela- 
tively positive developments over the control group in several reviewed articles. This means that many of the students benefited from the intervention. It also revealed that their peers with usual developmental patterns benefited from the strategies as well, even though it was prepared for the students with special needs. Based on the findings of this research, this research makes suggestions for practice and further research. First, the studies revealed that students with special needs succeeded in solving problems by applying appropriate interventions. In this context, experts working with students with special needs should get involved in professional development programs about the problem-solving stages as well as cognitive and metacognitive strategies with which students can successfully implement the problem-solution strategies. Second, it appears that 12 studies used the 'Solve It!' strategy to develop the problem-solving skills of students with special needs. Hence, students with special needs should be the subjects of the studies examining the 'Solve It!' strategy to support their problem-solving skills. In this context, future studies can test the effect of each of cognitive and metacognitive strategy element within the 'Solve It!' strategy and examine the effects of this strategy on problem-solving performance of the students with special needs. Thus, some programs can be prepared to solve the problems. Third, the 'Solve It!' strategy can be recommended not only for students with special needs, but also for their peers with similar development disorders because it has the potential to increase their problem-solving performance.

\section{References}

Baki, K. (2014). The effects of schema-based strategy instruction on the mathematical word problem solving skills of students with intellectual disabilty. Master thesis, Anadolu University, Eskişehir.

Bryant, D. P., Bryant, B. R., \& Hammill, D. D. (2000). Characteristic behaviors of students with LD who have teacher-identified math weaknesses. Journal of Learning Disabilities, 33, 168-177.

Carpenter, T. P., Ansell, E., Franke, M. L., Fennema, E., \& Weisbeck, L. (1993) Models of problem solving: A study of kindergarten children's problem-solving processes. Journal for Research in Mathematics Education, 24(5), 428-441.

Case, L., \& Harris, K. R. (1988). Self-Instructional Strategy Training: Improving the Mathematical Problem Solving Skills of Learning Disabled Students. Speeches/Conference Papers.

Cawley, J. \& Miller, J. (1986). Selected views on metacognition, arithmetic problem solving, and learning disabilities. Learning Disabilities Focus, 2(1), 36-48.

Cawley, J. F., Parmar, R., Yan, W., \& Miller, J. H. (1998). Arithmetic computation performance of students with learning disabilities: Implications for curriculum. Learning Disabilities Research and Practice 13(2), 68-74

*Chung K. H. \& Tam, Y. H. (2005). Effects of cognitive-based instruction on mathematical problem solving by learners with mild intellectual disabilities. Journal of Intellectual and Developmental Disability, 30(4) 207-216.

*Coughlin, J., \& Montague, M. (2010). The effects of cognitive strategy instruction on the mathematical problem solving ability of adolescents with spina bifida. Journal of Special Education, 45, 171-183.

*Daniel, G. E. (2003). Effects of cognitive strategy instruction on the mathematical problem solving of middle school students with learning disabilities. Doctoral dissertation, Ohio State University, Columbus.
DeCorte, E., Greer, B., \& Verschaffel, L. (1996). Mathematics teaching and learning. In D. Berliner \& R. Calfee (Eds.), Handbook of educational psychology. New York: Macmillan.

Fuchs, L. S., Fuchs, D., Prentice, K., Hamlett, C. L., Finelli, R. \& Courey, S. J. (2004). Enhancing mathematical problem solving among third-grade students with schema-based instruction. Journal of Educational Psychology, 96(4), 635-647.

Geary, D. C. (2004). Mathematics and learning disabilities. Journal of Learning Disabilities, 37, 4-15.

Güzel-Özmen, R. (2008). Students with learning disabilities. İ. H. Diken (Ed.), Students with special needs and special education (pp. 333-367). Ankara: Pegem Academy.

Happe, F., Booth, R., Charlton, R., \& Hughes, C. (2006). Executive function deficits in autism spectrum disorders and attention- deficit/hyperactivity disorder: Examining profiles across domains and ages. Brain and Cognition, $61,25-39$

Hughes, C. A., Maccini, P., \& Gagnon, J. C. (2003). Interventions that positively impact the performance of students with learning disabilities in secondary general education classes. Learning Disabilities: A Multidisciplinary Journal, 12, 101-111.

Hunt, J. H., \& Vasquez, E. (2014). Effects of ratio strategies intervention on knowledge of ratio equivalence for students with learning disability. The Journal of Special Education, 48, 180-190.

Iseman, J. S. \& Naglieri, J. A. (2011). A cognitive strategy instruction to improve math calculation for children with ADHD and LD: A randomized controlled study. Journal of Learning Disabilities, 44, 184-195.

Ives, B. (2007). Graphic organizers applied to secondary algebra instruction for students with learning disorders. Learning Disabilities Research \& Practice, 22, 110-118.

Jitendra, A. K., Star, J. R., Starosta, K., Leh, J. M., Sood, S., Caskie, G., \& Mack, T. R. (2009). Improving seventh grade students' learning of ratio and proportion: The role of schema-based instruction. Contemporary Educational Psychology, 34(3), 250-264.

Jonassen, D. H. (2003). Using cognitive tools to represent problems. Journal of Research on Technology in Education 35(3), 142-163.

*Karabulut, A. (2015). Effectiveness of "understand and solve!" strategy instruction on mathematical problem solving of students with mild intellectual disabilities. Doctoral dissertation, Gazi University, Ankara.

Karabulut, A., \& Özkubat, U. (2019). Problem Solving. Alptekin, S. (Ed), Mathematics in Special Education (pp. 263-293). Eğiten.

*Karabulut, A., \& Özmen, E. R. (2018). Effect of "understand and solve!" strategy instruction on mathematical problem solving of students with mild intellectual disabilities. International Electronic Journal of Elementary Education, 11(2), 77-90.

Karabulut, A., Yıkmış, A., Özak, H., \& Karabulut, H. (2015). The effect of schema based problem solving strategy on problem solving performance of students with intellectual disabilities. Abant Izzet Baysal University Journal of Education Faculty, 15, 243-258. 
Keeler, M. L. \& Swanson, H. L. (2001). Does strategy knowledge influence working memory in children with mathematical disabilities? Journal of Learning Disabilities, 34(5), 418, 439.

Kot, M. \& Yıkmış, A. (2018). The effects of schema-based ınstruction on the mathematical problem solving skills of children with mental retardation. Journal of Kalem Education and Human Sciences, 8(2), 335-358.7

Krawec, J. L. (2010). Problem representation and mathematical problem solving of students with varying abilities. Doctoral dissertation, University of Miami, Florida.

*Krawec, J., Huang, J. Montague M., Kressler B.\& Alba A. M. (2013). The effects of cognitive strategy instruction on knowledge of math problem-solving processes of middle school students with learning disabilities. Learning Disability Quarterly, 36(2) 80 -92

Mayer, R. E. (1985). Mathematical ability. In R. J. Sternberg (Ed.), Human abilities: An information processing approach (pp. 127-150). San Francisco, CA: Freeman.

Moher, D., A. Liberati, J. Tetzlaff, D. G. Altman, \& The PRISMA Group (2009). Preferred reporting items for systematic reviews and meta-analyses: The prisma statement. PLoS Medicine, 6(6), e1000097.

Miller, S., \& Mercer, C. (1997). Education aspects of mathematics disabilities. Journal of Learning Disabilities, $30(1), 47-56$.

Miller, S., Butler, F., \& Lee, K. (1998). Validated practices for teaching mathematics to students with learning disabilities: A review of the literature. Focus on Exceptional Children, 31(1), 1-24.

* Montague, M. (1984). The effect of cognitive strategy training on verbal math problem solving performance of learning disabled adolescents. Doctoral dissertation, University of Arizona, Arizona.

Montague, M. (1991). Gifted and learning-disabled gifted students' knowledge and use of mathematical problem-solving strategies. Journal for Education of the Gifted, 14, 393-411.

*Montague, M. (1992). The effects of cognitive and metacognitive strategy instruction on mathematical problem solving of middle school students with learning disabilities. Journal of Learning Disabilities, 25,230-248.

Montague, M. (1997). Cognitive strategy instruction in mathematics for students with learning disabilities. Journal of Learning Disabilities, 30, 164-177.

Montague, M. (1998). Cognitive Strategy Instruction in Mathematics for Students with Learning Disabilities. In Rivera, D. P. (Ed.), Mathematics Education for Students with Learning Disabilities (p. 177-200). Pro-ed, Inc.

Montague, M. (2008). Self-regulation strategies to improve mathematical problem solving for students with learning disabilities. Learning Disability Quarterly, 31, 37-44.

*Montague M., Enders C., \& Dietz, S. (2011). Effects of cognitive strategy instruction on math problem solving of middle school students with learning disabilities. Learning Disability Quarterly, 34(4) $262-272$.
Montague, M. \& Applegate, B. (1993). Mathematical problem solving characteristics of middle school students with learning disabilities. Journal of Special Education, 27, 175-201.

Montague, M., Applegate, B., \& Marquard, K. (1993). Cognitive strategy instruction and mathematical problem-solving performance of students with learning disabilities. Learning Disabilities Research and Practice, 8, 223-232.

*Montague, M. \& Bos, C. (1986). The effect of cognitive strategy training on verbal math problem solving performance of learning disabled adolescents. Journal of Learning Disabilities, 19, 26-33.

*Montague, M., Krawec, J., Enders, C., \& Dietz, S. (2014). The effects of cognitive strategy instruction on math problem solving of middle-school students of varying ability. Journal of Educational Psychology, 106, 469-481.

Montague, M., Warger, C, \& Morgan, H. (2000). Solve It!: Strategy instruction to improve mathematical problem solving. Learning Disabilities Research and Practice, $15,110-116$.

Özkubat, U. (2019). An examination of the relationships between cognitive strategies and metacognitive functions used during mathematical problem solving by the students with learning disabilities, low achieving, and average achieving. Doctoral dissertation, Gazi University, Ankara.

Özkubat, U., \& Özmen, E. R. (2018). Analysis of mathematical problem solving process of students with learning disability: Implementation of think aloud protocol. Ankara University Faculty of Educational Sciences Journal of Special Education, 19(1), 155-180.

Özsoy, G. (2005). The relationship between problem solving skills and mathematical achievement. Gazi University Journal of Gazi Educational Faculty, 25(3), 179-190.

Özsoy, G. (2017). The effect of metacognitive strategy training on mathematical problem solving achievement. International Electronic Journal of Elementary Education, 1(2), 67-82.

Parmar, S., \& Cawley, J. (1997). Preparing teachers to teach mathematics to students with learning disabilities. Journal of Learning Disabilities, 30(2), 188-197.

Passolunghi, M. C., Marzocchi, G. M., \& Fiorillo, F. (2005). Selective effect of inhibition of literal or numerical irrelevant information in children with attention deficit hyperactivity disorder (ADHD) or arithmetic learning disorder (ALD). Developmental Neuropsychology, 28, 731-753.

Polya, G. (1957). How to solve it. Garden City, N.Y.: Doubleday-Anchor.

Powell, S. (2011). Solving word problems using schemas: A review of the literature. Learning Disabilities Research \& Practice, 26(2), 94-108.

Powell, S. R., Fuchs, L. S., Fuchs, D., Cirino, P. T., \& Fletcher, J. M. (2009). Do word-problem features differentially affect problem difficulty as a function of students' mathematics difficulty with and without reading difficulty?. Journal of Learning Disabilities, 42(2), 99-110. 
Reid, R. \& Lienemann, T. O. (2006). Self-regulated strategy development for students with learning disabilities. Teacher Education and Special Education,29(1), 3-11.

Rivera, D. (1997). Mathematics education and students with learning disabilities: Introduction to special series. Journal of Learning Disabilities, 30(1), 19-68.

Schurter, W. A. (2002). Comprehension monitoring: An aid to mathematical problem solving. Journal of Developmental Education, 26(2), 22- 33.

Swanson, H. L. \& Jerman, O. (2006) Math disabilities: A selective meta-analysis of the literature. Review of Educational Research, 76, 249-274.

Sweeney, C. M. (2010). The metacognitive functioning of middle school students with and without learning disabilities during mathematical problem solving. Doctoral dissertation, University of Miami, Florida.

Tufan, S. \& Aykut, Ç. (2018). The effect of schema based strategy and self- monitoring on problem solving performance of students with mild intellectual disability. Elementary Education Online, 17(2), 613-641.

Tuncer, A. T. (2009). The effects of schema based word problem solving strategy on problem solving performance of students with visual impairment. Education and Science, 34(153), 183-197.

Van Garderen, D. (2006). Spatial visualization, visual imagery, and mathematical problem solving of students with varying abilities. Journal of Learning Disabilities, 39(6), 496-506.

Van Garderen, D. (2007). Teaching students with LD to use diagrams to solve mathematical word problems. Journa of Learning Disabilities, 40, 540-553.

*Whitby, P. J. S. (2012). The effects of solve it! on the mathematical word problem solving ability of adolescents with autism spectrum disorders. Focus on Autism and Other Developmental Disabilities, 28(2) 78-88.

Xin, Y. P., \& Jitendra, A. (1999). The effects of instruction in solving mathematical word problems for students with learning problems: A meta-analysis. Journal of Special Education, 32, 207-225.

* See Table 4. 
Table 4. Research Properties

\begin{tabular}{|c|c|c|c|c|c|c|c|c|c|}
\hline Research and aim & Participants & $\begin{array}{l}\text { Grade } \\
\text { and } \\
\text { age level }\end{array}$ & Diagnosis & Target skills & $\begin{array}{l}\text { Research } \\
\text { designs }\end{array}$ & $\begin{array}{l}\text { Intervention } \\
\text { environment }\end{array}$ & $\begin{array}{l}\text { Generalization } \\
\text { and follow up }\end{array}$ & Reliability & Results \\
\hline $\begin{array}{l}\text { Chung and Tam (2005) } \\
\text { Aim: Examined the effects } \\
\text { of different approaches to } \\
\text { teaching learners with mild } \\
\text { intellectual disabilities to } \\
\text { solve mathematical word } \\
\text { problems. }\end{array}$ & $\begin{array}{l}22 \text { Male } \\
8 \text { Female }\end{array}$ & $\begin{array}{c}\text { GL: - } \\
\text { AL: 8-12 }\end{array}$ & ID & $\begin{array}{l}\text { Mathematical } \\
\text { problems } \\
\text { including two } \\
\text { steps addition } \\
\text { and subtraction }\end{array}$ & $\begin{array}{l}\text { Cross } \\
\text { subjects } \\
\text { experi- } \\
\text { mental } \\
\text { design }\end{array}$ & $\begin{array}{l}\text { Empty room } \\
\text { in school }\end{array}$ & $\begin{array}{l}\text { G:- } \\
\text { F:- }\end{array}$ & $\begin{array}{l}\text { RO: + } \\
\text { AR: - }\end{array}$ & $\begin{array}{l}\text { Students who were } \\
\text { trained in cognitive } \\
\text { strategy teach- } \\
\text { ing solved more } \\
\text { problems than other } \\
\text { groups correctly. }\end{array}$ \\
\hline $\begin{array}{l}\text { Coughlin and Montague } \\
(2011) \\
\text { Aim: Investigate the effects } \\
\text { of cognitive strategy instruc- } \\
\text { tion on the mathematical } \\
\text { problem solving of three } \\
\text { adolescents with spina } \\
\text { bifida. }\end{array}$ & $\begin{array}{c}3 \text { Male } \\
1 \text { Female }\end{array}$ & $\begin{array}{l}\text { GL: } 9-10 \\
\text { AL: } 15-17 .\end{array}$ & SB & $\begin{array}{l}\text { One and two- } \\
\text { step mathemat- } \\
\text { ical problems } \\
\text { in the Solve It! } \\
\text { program }\end{array}$ & $\begin{array}{l}\text { Multiple } \\
\text { baseline } \\
\text { across in- } \\
\text { dividuals } \\
\text { design }\end{array}$ & $\begin{array}{l}\text { Support } \\
\text { room }\end{array}$ & $\begin{array}{l}\text { G:- } \\
F:+\end{array}$ & $\begin{array}{l}\text { RO: - } \\
\text { AR: + }\end{array}$ & $\begin{array}{l}\text { The mathematical } \\
\text { problem-solving skills } \\
\text { of all participants in } \\
\text { the study increased } \\
\text { significantly. }\end{array}$ \\
\hline $\begin{array}{l}\text { Daniel (2003) } \\
\text { Aim: Investigate the effects } \\
\text { of cognitive strategy instruc- } \\
\text { tion on the mathematical } \\
\text { problem-solving perfor- } \\
\text { mance of middle school } \\
\text { students with learning } \\
\text { disabilities. }\end{array}$ & $\begin{array}{l}12 \text { male } \\
6 \text { female }\end{array}$ & $\begin{array}{l}\text { GL: } 6,7,8 \\
\text { AL: } 11-13\end{array}$ & $\begin{array}{l}\text { AA, LD, } \\
\text { TD }\end{array}$ & $\begin{array}{l}\text { Math problems } \\
\text { in Solve It! } \\
\text { program }\end{array}$ & $\begin{array}{l}\text { A quasi } \\
\text { experi- } \\
\text { mental, } \\
\text { control } \\
\text { group } \\
\text { time } \\
\text { series } \\
\text { design }\end{array}$ & $\begin{array}{l}\text { Support } \\
\text { room }\end{array}$ & $\begin{array}{l}\text { G:- } \\
\text { F:+ }\end{array}$ & $\begin{array}{l}\text { RO: - } \\
\text { AR: - }\end{array}$ & $\begin{array}{l}\text { Mathematics } \\
\text { problem-solving per- } \\
\text { formance of students } \\
\text { with learning disabili- } \\
\text { ties improved. }\end{array}$ \\
\hline $\begin{array}{c}\text { Karabulut (2015) } \\
\text { Aim: Evaluate the impact } \\
\text { of Solve It! intervention } \\
\text { in solving mathematical } \\
\text { problems. }\end{array}$ & $\begin{array}{c}1 \text { male } \\
2 \text { female }\end{array}$ & $\begin{array}{c}\text { GL: } 5 \\
\text { AL: } 11-12\end{array}$ & ID & $\begin{array}{l}\text { Substitution } \\
\text { problems } \\
\text { involving one } \\
\text { step addition } \\
\text { and subtraction }\end{array}$ & $\begin{array}{l}\text { A multiple } \\
\text { probe } \\
\text { design } \\
\text { across } \\
\text { subjects }\end{array}$ & $\begin{array}{l}\text { Empty } \\
\text { classroom in } \\
\text { the school }\end{array}$ & $\begin{array}{c}\text { G:+F } \\
:+\end{array}$ & $\begin{array}{l}\text { RO: + } \\
\text { AR: + }\end{array}$ & $\begin{array}{l}\text { 'Solve it' strategy was } \\
\text { identified as effective } \\
\text { in the solution of } \\
\text { change problems } \\
\text { involving a gradual } \\
\text { addition and subtrac- } \\
\text { tion process. }\end{array}$ \\
\hline $\begin{array}{l}\text { Karabulut and Özmen } \\
(2018) \\
\text { Aim: Examine the effects of } \\
\text { Solve It! Strategy on change } \\
\text { problems. }\end{array}$ & $\begin{array}{c}1 \text { male } \\
2 \text { female }\end{array}$ & $\begin{array}{c}\text { GL: } 5 \\
\text { AL: } 11-12\end{array}$ & ID & $\begin{array}{l}\text { Substitution } \\
\text { problems } \\
\text { involving one } \\
\text { step addition } \\
\text { and subtraction }\end{array}$ & $\begin{array}{l}\text { A multiple } \\
\text { probe } \\
\text { design } \\
\text { across } \\
\text { subjects }\end{array}$ & $\begin{array}{l}\text { Empty } \\
\text { classroom in } \\
\text { the school }\end{array}$ & $\begin{array}{l}\text { G:+ } \\
\text { F:+ }\end{array}$ & $\begin{array}{l}\text { RO: + } \\
\text { AR: + }\end{array}$ & $\begin{array}{l}\text { 'Solve It!' strategy was } \\
\text { effective in teaching } \\
\text { students with mild } \\
\text { intellectual disabilities } \\
\text { solving change } \\
\text { problems including } \\
\text { one-step addition } \\
\text { and subtraction, they } \\
\text { maintained their } \\
\text { skills and generalized } \\
\text { their skills to different } \\
\text { problem types, } \\
\text { two-step change } \\
\text { problems. }\end{array}$ \\
\hline $\begin{array}{c}\text { Krawec, Huang, Montague, } \\
\text { Kressler and De Alba (2013) } \\
\text { Aim: Investigate the effec- } \\
\text { tiveness of Solve It! instruc- } \\
\text { tion on students' knowledge } \\
\text { of math problem-solving } \\
\text { strategies. }\end{array}$ & $\begin{array}{l}82 \text { male } \\
79 \text { female }\end{array}$ & $\begin{array}{l}\text { GL: 7, } 8 \\
\text { AL: }\end{array}$ & $\begin{array}{c}\text { AA, LD, } \\
\text { TD }\end{array}$ & $\begin{array}{l}\text { Math problems } \\
\text { in the Solve It! } \\
\text { program }\end{array}$ & $\begin{array}{l}\text { Pretest } \\
\text { posttest } \\
\text { design } \\
\text { and struc- } \\
\text { tured } \\
\text { interviews }\end{array}$ & $\begin{array}{l}\text { Education } \\
\text { classroom }\end{array}$ & $\begin{array}{l}\text { G:- } \\
\text { F:- }\end{array}$ & $\begin{array}{l}\text { RO: + } \\
\text { AR: + }\end{array}$ & $\begin{array}{l}\text { Students participating } \\
\text { in the intervention } \\
\text { program used prob- } \\
\text { lem-solving strategies } \\
\text { more. Students with } \\
\text { learning disabilities } \\
\text { use relatively little } \\
\text { strategy than their } \\
\text { peers while solving } \\
\text { problems. } \\
\end{array}$ \\
\hline $\begin{array}{l}\text { Montague (1984) } \\
\text { Aim: Investigate the } \\
\text { effectiveness of an eight- } \\
\text { step strategy designed to } \\
\text { enable students to read, } \\
\text { understand, carry out, and } \\
\text { check verbal math problems } \\
\text { that are encountered in the } \\
\text { general math curriculum at } \\
\text { the secondary level. }\end{array}$ & $\begin{array}{c}5 \text { male } \\
1 \text { female }\end{array}$ & $\begin{array}{l}\text { GL: } 10,12 \\
\text { AL: } 15-19\end{array}$ & LD & $\begin{array}{l}\text { One, two and } \\
\text { three step } \\
\text { mathematical } \\
\text { problems }\end{array}$ & $\begin{array}{l}\text { A multiple } \\
\text { baseline } \\
\text { design } \\
\text { across } \\
\text { individ- } \\
\text { uals }\end{array}$ & $\begin{array}{l}\text { Support } \\
\text { room and } \\
\text { education } \\
\text { classroom }\end{array}$ & $\begin{array}{l}\text { G:+ } \\
\text { F:+ }\end{array}$ & $\begin{array}{l}\text { RO: + } \\
\text { AR: + }\end{array}$ & $\begin{array}{l}\text { Mathematics } \\
\text { problem-solving per- } \\
\text { formance of students } \\
\text { with learning disabili- } \\
\text { ties has improved. }\end{array}$ \\
\hline $\begin{array}{l}\text { Montague (1992) } \\
\text { Aim: Investigate the effect of } \\
\text { cognitive and metacognitive } \\
\text { strategy teaching on solving } \\
\text { mathematical problems. }\end{array}$ & $\begin{array}{c}3 \text { male } \\
3 \text { female }\end{array}$ & $\begin{array}{c}\text { GL: } 6,7,8 \\
\text { AL: } 12-14\end{array}$ & LD & $\begin{array}{l}\text { One, two and } \\
\text { three-step } \\
\text { mathematical } \\
\text { problems with } \\
\text { exact and deci- } \\
\text { mal numbers }\end{array}$ & $\begin{array}{l}\text { A multiple } \\
\text { probe } \\
\text { design } \\
\text { across } \\
\text { subjects }\end{array}$ & $\begin{array}{l}\text { Support } \\
\text { room }\end{array}$ & $\begin{array}{l}\text { G:+ } \\
\text { F:+ }\end{array}$ & $\begin{array}{l}\text { RO: - } \\
\text { AR: - }\end{array}$ & $\begin{array}{l}\text { It is stated that the } \\
\text { model in which cogni- } \\
\text { tive and metacogni- } \\
\text { tive strategies were } \\
\text { taught together in } \\
\text { solving mathematical } \\
\text { problems was more } \\
\text { effective than the } \\
\text { models in which the } \\
\text { strategies were han- } \\
\text { dled separately and } \\
\text { teaching cognitive } \\
\text { and metacognitive } \\
\text { strategies improved } \\
\text { the performance } \\
\text { of the students in } \\
\text { solving mathematical } \\
\text { problems. }\end{array}$ \\
\hline
\end{tabular}


Table 4 (Cont.). Research Properties

\begin{tabular}{|c|c|c|c|c|c|c|c|c|c|}
\hline Research and aim & Participants & $\begin{array}{l}\text { Grade } \\
\text { and } \\
\text { age level }\end{array}$ & Diagnosis & Target skills & $\begin{array}{l}\text { Research } \\
\text { designs }\end{array}$ & $\begin{array}{l}\text { Intervention } \\
\text { environment }\end{array}$ & $\begin{array}{l}\text { Generalization } \\
\text { and follow up }\end{array}$ & Reliability & Results \\
\hline $\begin{array}{l}\text { Montague and Bos (1986) } \\
\text { Aim: Investigate the effect } \\
\text { of an eight-step cognitive } \\
\text { strategy on verbal math } \\
\text { problem-solving perfor- } \\
\text { mance of six learning } \\
\text { disabled adolescents. }\end{array}$ & $\begin{array}{c}5 \text { male } \\
1 \text { female }\end{array}$ & $\begin{array}{l}\text { GL: } 10,12 \\
\text { AL: } 15-19\end{array}$ & LD & $\begin{array}{l}\text { One, two and } \\
\text { three-step } \\
\text { mathematical } \\
\text { problems }\end{array}$ & $\begin{array}{l}\text { A multiple } \\
\text { baseline } \\
\text { design } \\
\text { across } \\
\text { individ- } \\
\text { uals }\end{array}$ & $\begin{array}{l}\text { Support } \\
\text { room and } \\
\text { education } \\
\text { classroom }\end{array}$ & $\begin{array}{l}\text { G:+ } \\
\text { F:+ }\end{array}$ & $\begin{array}{l}\text { RO: } \\
+ \text { +AR: + }\end{array}$ & $\begin{array}{l}\text { Mathematics } \\
\text { problem-solving } \\
\text { performance of } \\
\text { students with } \\
\text { learning disabilities } \\
\text { improved. }\end{array}$ \\
\hline $\begin{array}{c}\text { Montague, Enders and Dietz } \\
(2011) \\
\text { Aim: Improve mathematical } \\
\text { problem solving for middle } \\
\text { school students with learn- } \\
\text { ing disabilities by imple- } \\
\text { menting a research-based } \\
\text { instructional program in } \\
\text { inclusive general education } \\
\text { math classes. }\end{array}$ & $\begin{array}{c}359 \text { Male } \\
420 \text { Female }\end{array}$ & $\begin{array}{l}\text { GL: } 8 \\
\text { AL: - }\end{array}$ & LD, TD & $\begin{array}{l}\text { Mathematical } \\
\text { problems with } \\
\text { exact and deci- } \\
\text { mal numbers }\end{array}$ & $\begin{array}{l}\text { Cluster } \\
\text { rand- } \\
\text { omized } \\
\text { design }\end{array}$ & $\begin{array}{l}\text { Education } \\
\text { classroom }\end{array}$ & $\begin{array}{l}\text { G:+ } \\
\text { F:+ }\end{array}$ & $\begin{array}{l}\text { RO: + } \\
\text { AR: + }\end{array}$ & $\begin{array}{l}\text { Students who } \\
\text { participated in the } \\
\text { intervention in } \\
\text { all talent groups } \\
\text { received higher } \\
\text { points. }\end{array}$ \\
\hline $\begin{array}{l}\text { Montague, Krawec, Enders } \\
\text { and Dietz (2014) } \\
\text { Aim: Evaluate the impact } \\
\text { of "Solve It!" intervention } \\
\text { in solving mathematical } \\
\text { problems. }\end{array}$ & $\begin{array}{l}453 \text { male } \\
606 \text { female }\end{array}$ & $\begin{array}{l}\text { GL: } 7 \\
\text { AL: - }\end{array}$ & LD, TD & $\begin{array}{l}\text { Mathematical } \\
\text { problems with } \\
\text { exact and deci- } \\
\text { mal numbers }\end{array}$ & $\begin{array}{l}\text { Cluster } \\
\text { rand- } \\
\text { omized } \\
\text { design }\end{array}$ & $\begin{array}{l}\text { Education } \\
\text { classroom }\end{array}$ & $\begin{array}{l}\text { G:+ } \\
\text { F:+ }\end{array}$ & $\begin{array}{l}\text { RO: + } \\
\text { AR: + }\end{array}$ & $\begin{array}{l}\text { Students who } \\
\text { participated in the } \\
\text { intervention in } \\
\text { all talent groups } \\
\text { received higher } \\
\text { points. }\end{array}$ \\
\hline $\begin{array}{l}\text { Whitby (2012) } \\
\text { Aim: Investigate the use of } \\
\text { the Solve It! Problem Solving } \\
\text { Routine for students with } \\
\text { autism spectrum disorders. }\end{array}$ & $\begin{array}{c}2 \text { male } \\
1 \text { female }\end{array}$ & $\begin{array}{c}\text { GL: } 7,8 \\
\text { AL: } 13-14\end{array}$ & ASD & $\begin{array}{l}\text { One and two- } \\
\text { step mathemat- } \\
\text { ical problems } \\
\text { in the Solve It! } \\
\text { program }\end{array}$ & $\begin{array}{l}\text { A multiple } \\
\text { baseline } \\
\text { across } \\
\text { partici- } \\
\text { pants }\end{array}$ & $\begin{array}{l}\text { Support } \\
\text { room and } \\
\text { education } \\
\text { classroom }\end{array}$ & $\begin{array}{l}\text { G:+ } \\
\text { F:+ }\end{array}$ & $\begin{array}{l}\text { RO: + } \\
\text { AR: + }\end{array}$ & $\begin{array}{l}\text { It is stated that all of } \\
\text { the three students } \\
\text { who participated in } \\
\text { the study improved } \\
\text { their performance } \\
\text { in solving mathe- } \\
\text { matical problems. }\end{array}$ \\
\hline
\end{tabular}

Keys: AL: Age Level; GL: Grade Level; LD: Learning Disability; ID: Intellectual Disabilities; SB: Spina Bfida; ASD: Autism Spectrum Disorders; TD: Typically Development G: Generalization; F: Follow Up; RO: Reliability of Observers; AR: Intervention Reliability. 